\title{
ARTIKEL
}

\section{Toezichthouders op straat}

\section{Een internationaal vergelijkende benadering}

\author{
Jan Terpstra \& Bas van Stokkom
}

\section{$1 \quad$ Inleiding}

De afgelopen ruim twintig jaar is een nieuwe verdeling ontstaan in de verantwoordelijkheden voor veiligheidszorg. De zorg voor veiligheid wordt niet meer gezien als exclusieve taak van de politie. ${ }^{1}$ Als onderdeel van deze ontwikkeling zijn er naast de politie andere, zowel publieke, als private, toezichthouders en handhavers werkzaam. Deze zijn te vinden zowel in het publieke domein (op straat, plein, markt of in horecagebied), als in semipublieke gebieden die privaat eigendom zijn, maar die door burgers vaak als publiek (toegankelijk) terrein worden ervaren (zoals grote winkelcentra of bedrijventerreinen). Deze ontwikkelingen treden niet alleen op in Nederland, maar ook in veel andere landen, zowel binnen als buiten Europa.

In de (vooral Engelstalige) internationale wetenschappelijke literatuur wordt de opkomst van deze nieuwe toezichthouders en handhavers meestal beschreven in termen van plural policing. ${ }^{2}$ De meeste studies over plural policing hebben betrekking op Angelsaksische landen, zoals Engeland en Wales, Canada, de USA en Australië. Deze pluralisering van toezicht en handhaving roept vele, zowel praktisch-organisatorische, als meer fundamentele vragen op. Het is daarom goed na te gaan hoe deze ontwikkeling in andere landen is verlopen en op welke wijze men daarop heeft gereageerd. Bovendien biedt vergelijkend onderzoek aanknopingspunten om te leren van ervaringen die in andere landen zijn opgedaan.

Om deze reden hebben wij voor vier verschillende landen de pluralisering van de politiefunctie in kaart gebracht, en is nagegaan welke factoren en omstandigheden daaraan hebben bijgedragen. De ontwikkelingen en hun achtergronden zijn daarbij vergeleken met die in Nederland. Nagegaan is welke problemen zich voordoen in de verschillende onderzochte landen en welke antwoorden men daarop heeft proberen te vinden. We beperken ons daarbij tot het toezicht op straat (inclusief privaat beheerde winkelgebieden); onder meer toezichthouders en handhavers in het openbaar vervoer, op luchthavens en in park- en bosgebieden

1 J. Terpstra, L. Gunther Moor \& B. van Stokkom, De kerntakendiscussie in Nederland. Retoriek en realiteit, in: B. van Stokkom, J. Terpstra \& L. Gunther Moor (e.a.) (red.), De politie en haar opdracht. De kerntakendiscussie voorbij, Antwerpen: Maklu 2010, p. 25-50.

2 A. Crawford, S. Lister, S. Blackburn \& J. Burnett, Plural Policing: The Mixed Economy of Visible Patrols in England and Wales, Bristol: Policy Press 2005; T. Jones \& T. Newburn, Understanding plural policing, in: T. Jones \& T. Newburn (red.), Plural policing: A comparative perspective, London: Routledge 2006, p. 1-11. 
zijn niet meegenomen. Bij deze vergelijking is ook aandacht geschonken aan de verhouding tussen niet-politiële toezichthouders en handhavers in het (semi)publieke domein en de reguliere politie. Bij deze vergelijking staat telkens het Nederlands perspectief centraal.

In dit artikel worden de bevindingen gepresenteerd van een onderzoek waarin twee Angelsaksische landen en twee continentale landen zijn bestudeerd. Het gaat hier om Engeland en Wales, Canada, België en Oostenrijk. Deze landen zijn geselecteerd op grond van verschillende overwegingen. In alle vier onderzochte landen is sprake van plural policing. Tegelijk verschilt de wijze waarop deze vorm heeft gekregen tussen deze landen. Daarbij heeft de analyse zich beperkt tot landen die qua context niet al te zeer verschillen van Nederland. Om die reden worden landen als Zuid-Afrika en Brazilië hier buiten beschouwing gelaten hoewel beide beschikken over een omvangrijke private veiligheidssector die uiteenlopende publieke functies vervult. Wat betreft de verschillen in plural policing is onder meer gekeken naar de mate waarin veiligheidszorg en toezicht in de publieke ruimte zijn beïnvloed door neoliberale opvattingen. ${ }^{3}$ Aan de ene kant is gekozen voor Oostenrijk als voorbeeld van een continentaal Europees land waar de overheid nog altijd een sterke, traditionele positie inneemt. Hier is in relatief beperkte mate sprake van een neoliberaal beleid waarin het terugdringen van de overheid en het creëren van meer ruimte voor de markt voorop staan. Aan de andere kant staat Canada, een land met niet alleen een belangrijke positie voor private beveiligingsbedrijven in het toezicht in de publieke ruimte, maar ook een zekere vermarkting van de politie. ${ }^{4}$ In Canada beperkt dit onderzoek zich tot de provincie Ontario. De omvang van het land, alsmede de federale structuur met een grote diversiteit op het terrein van politie en toezicht maken een nadere toespitsing op één provincie noodzakelijk. Engeland en Wales zijn geselecteerd als voorbeeld van een Europees land met een relatief grote invloed van neoliberaal beleid, ook in de veiligheidszorg. Tot slot, in België is (evenals in Nederland, zij het overigens op een wat andere manier) het beleid ten aanzien van toezicht in de publieke ruimte bepaald door zowel neoliberale, als meer continentale of Rijnlandse ${ }^{5}$ elementen.

Voor elk van de vier onderzochte landen is informatie verzameld over de pluralisering van toezicht en handhaving in het publiek domein. Daartoe zijn vele documenten bestudeerd waaronder wettelijke regelingen, beleidsnota's, wetenschappelijke publicaties en relevante stukken in pers en media. Bovendien zijn in elk land sleutelpersonen geïnterviewd (in totaal 25), die op verschillende posities werkzaam zijn, zoals ambtenaren bij nationale overheden, vertegenwoordigers

3 Zie voor een discussie daarover: A. Crawford, Networked governance and the post-regulatory state? Steering, rowing and anchoring the provision of policing and security, Theoretical Criminology 2006, 10 (4), p. 449-479; I. Loader \& N. Walker, Civilizing Security, Cambridge: Cambridge University Press 2007.

4 G. Rigakos, The New Parapolice: Risk Markets and Commodified Social Control, Toronto: University of Toronto Press 2002; G. Rigakos \& C. Leung, Canada, in: T. Jones \& T. Newburn (red.), Plural policing: A comparative perspective, Londen: Routledge 2006, p. 126-138.

5 M. Albert, Kapitalisme contra Kapitalisme, Amsterdam/Antwerpen: Contact 1992. 
van lokale overheden, de politie, diensten toezicht $\&$ handhaving, en de private beveiligingssector. Omdat de organisatie en het functioneren van de nieuwe toezicht- en handhavingsfuncties in België en Oostenrijk sterk lokaal bepaald zijn, zijn in beide landen enkele lokale casestudies uitgevoerd. ${ }^{6}$

In deze studie gaan we niet in op theoretische vragen rond plural policing. We beogen de belangrijkste empirische bevindingen in de genoemde landen op een rij te zetten. In de laatste paragraaf wordt nagegaan wat die bevindingen kunnen leren voor het Nederlandse beleid: welke antwoorden kunnen worden gevonden op de problemen die plural policing met zich meebrengt, waaronder coördinatieproblemen en een gebrek aan democratische verantwoording? We presenteren daartoe twee beleidsperspectieven.

Dit artikel is als volgt opgebouwd. Eerst schetsen wij kort enkele belangrijke ontwikkelingen die in Nederland hebben geleid tot pluralisering van het toezicht- en handhavingswerk (par. 2). Vervolgens worden deze ontwikkelingen besproken voor de vier genoemde landen (par. 3). Daarna richt de aandacht zich op de belangrijkste verschillen tussen deze landen en Nederland (par. 4). Vier aspecten komen daarbij aan bod: formele regulering, scheiding of integratie, privatisering, en bevoegdheden. Ten slotte worden op basis van de onderzoeksbevindingen twee perspectieven geschetst voor toekomstig Nederlands beleid rond toezicht en handhaving in de openbare ruimte (par. 5).

\section{Pluralisering van toezicht en handhaving in Nederland}

De nieuwe toezichthouders en handhavers doen in Nederland hun entree eind jaren tachtig, begin jaren negentig. Een combinatie van factoren heeft daaraan destijds bijgedragen, zoals de sterke groei van de (veelvoorkomende) criminaliteit in Nederland vanaf de jaren zeventig, de toenemende politieke en beleidsmatige aandacht voor de aanpak van dit probleem, en de mogelijkheden die het aanvullend werkgelegenheidsbeleid bood om langdurig werklozen in te schakelen voor onder meer toezichttaken in de publieke ruimte. Met de komst van deze stadswachten (zoals ze meestal werden genoemd) ontstond de mogelijkheid buiten de politie om te voldoen aan de groeiende roep om meer toezicht op straat. De aanwezigheid van 'eigen' gemeentelijke toezichthouders bood bovendien gemeenten een middel om zelf direct problemen met betrekking tot leefbaarheid en veiligheid aan te pakken. Steeds vaker bleek het niet mogelijk voor deze problemen met succes een beroep te doen op de politie. Door de politie werd in toenemende mate het argument naar voren gebracht dat toezicht en de aanpak van 'leefbaarheidproblemen' niet tot de kerntaken van de politie zouden behoren ${ }^{7}$ of dat de politie niet over de middelen zou beschikken aan deze vragen tegemoet te komen, dit

6 Zie voor nadere toelichting op de onderzoeksmethoden: J. Terpstra, B. van Stokkom \& R. Spreeuwers, Who Patrols the Streets? An International Comparative Study to Plural Policing, The Hague: Eleven 2013.

7 C.D. van der Vijver, A.J. Meershoek \& D.F. Slobbe, Kerntaken van de politie, Zeist: Kerckebosch; Terpstra, Van Stokkom \& Gunther Moor 2010. 
ondanks de sterke groei die de Nederlandse politie de afgelopen decennia heeft doorgemaakt. ${ }^{8}$ De pluralisering van het toezicht- en handhavingswerk in de publieke ruimte in Nederland kan niet los worden gezien van de terugtrekkende beweging die de politie de afgelopen ongeveer vijftien jaar heeft doorgemaakt. In eerste instantie betrof dat een deels terugtrekken van de landelijke gebieden, later betrof het ook een terugtrekken van taken als toezicht, zichtbare aanwezigheid en de aanpak van preventie en overlast. ${ }^{9}$ Deze ontwikkeling werd bovendien bevorderd doordat gemeenten een steeds actievere rol gingen spelen in het lokaal integraal veiligheidsbeleid. De ambitieuzere rol van veel gemeenten in het veiligheidsbeleid vertaalde zich in een grotere en directere verantwoordelijkheid van gemeenten in de uitvoering van toezicht en handhaving op straat. ${ }^{10}$

Sinds in 1989 de eerste langdurig werklozen als stadswachten werden ingezet, ${ }^{11}$ heeft dit toezichtwerk zich verder ontwikkeld. De laatste tien jaar zijn deze stadswachten in dienst gekomen van veel grotere diensten Toezicht \& Handhaving. ${ }^{12}$ Sinds 1994 kunnen gemeenten ook buitengewone opsporingsambtenaren (boa's) aanstellen voor het publieke domein. Deze boa's hebben de bevoegdheid om voor nader omschreven overtredingen proces-verbaal op te stellen op grond waarvan een boete kan worden opgelegd. ${ }^{13}$

Mede in reactie op de opkomst van de stadswachten werd in 1993 de functie van politiesurveillant ingevoerd. In vergelijking met andere politiemensen hebben deze surveillanten een lager opleidingsniveau, minder opsporingsbevoegdheden en geen vuurwapens. De ministers van Justitie en van Binnenlandse Zaken stelden destijds dat de invoering van de politiesurveillanten nodig was gezien de groeiende behoefte aan toezicht en de verbrokkeling van toezichthoudende functies. De ministers erkenden dat de opkomst van stadswachten op zich wenselijk is, maar ze meenden tegelijk dat 'de politie zelf haar preventieve en toezichthoudende taken intensiever zou moeten uitvoeren'. De ministers spraken de verwachting uit dat indien de politiesurveillant is ingeburgerd er minder behoefte zal bestaan aan alternatieve vormen van algemeen toezicht buiten de politieorganisatie'. ${ }^{14}$ Gelet op de verdergaande pluralisering van de politie in Nederland

8 J. Haagsma e.a., De Sterkte van de Arm: feiten en mythes, Apeldoorn: Politie \& Wetenschap 2012.

9 S. Flight, A. Hartmann \& O. Nauta, Bestuurlijke strafbeschikking en bestuurlijke boete overlast. Evaluatie na drie jaar, Den Haag: WODC/Ministerie van Veiligheid en Justitie 2012; J. Terpstra, Particuliere beveiligers als publieke handhavers. De inzet van private boa's door gemeenten, Justitiële Verkenningen 2012, 38 (8), p. 35-50.

10 E. Bervoets, Gemeentelijk blauw. Het dagelijks werk van gemeentelijke handhavers in beeld. Apeldoorn/Rotterdam: Politie en Wetenschap/Lokale Zaken 2013; R. van Steden, Veelvormig en versnipperd: gemeentelijke toezichthouders en handhavers in het publieke domein, Den Haag: SMVP 2012.

11 A. Hauber, B. Hofstra, L. Toornvliet \& A. Zandbergen, Some new forms of functional social control in the Netherlands and their effects, British Journal of Criminology 1996, 36 (2), p. 199-219.

12 T. Eikenaar \& B. van Stokkom, Van stadswacht naar gemeentepolitie? Gemeentelijk toezicht en handhaving in de openbare ruimte, Apeldoorn: Politie \& Wetenschap 2014.

13 Van Steden 2012.

14 Kamerstukken II 1991/92, 22 306, nr. 3, Beleidsvoornemens politie 1992 p. 3 en 5, <http:// resourcessgd.kb.nl/SGD/19911992/PDF/SGD_19911992_0005184.pdf >. 
kan niet anders dan geconcludeerd worden dat deze verwachting niet is uitgekomen.

De mogelijkheden voor boa's om in de publieke ruimte handhavend op te treden, zijn ontleend aan twee wettelijke kaders. Sinds 2009 kent Nederland de Wet bestuurlijke boete overlast in de openbare ruimte. Sinds dat jaar kunnen gemeenten ook gebruikmaken van een bestuurlijke strafbeschikking overlast. In de praktijk wordt slechts gebruikgemaakt van de strafbeschikking, vooral om praktische en financiële redenen. ${ }^{15}$

Het aantal boa's in de publieke ruimte is de afgelopen twee decennia sterk gegroeid. Onder bepaalde voorwaarden hebben gemeenten de mogelijkheid tot het inhuren van private beveiligers voor boa-werkzaamheden in de publieke ruimte. In 2010 zou 14 procent van de gemeenten boa's van een particulier beveiligingsbedrijf inhuren. ${ }^{16}$ Met de keuze voor de inzet van private beveiligers als boa probeert men een flexibele organisatie te vormen: al naar gelang de behoefte kan de capaciteit worden aangepast. ${ }^{17}$ Terwijl hun publieke collega's over handboeien, pepperspray en wapenstok kunnen beschikken, beperkt dit zich voor 'private boa's' tot handboeien. Sinds eind 2013 zijn de ingehuurde (private) boa's in de publieke ruimte bevoegd te handhaven voor dezelfde feiten als hun publieke collega's. ${ }^{18}$

Volgens de boa-circulaire dient de politie de operationele regie te hebben over de boa's werkzaam in de publieke ruimte. Dit is een opmerkelijke constructie. De gemeente is immers in organisatorische, beleidsmatige en financiële zin verantwoordelijk voor deze handhavers. Verschillende recente onderzoeken laten zien dat deze operationele regie door de politie in de praktijk moeizaam functioneert. Voor de boa's is de afstand tot de politie vaak groot. De informatieoverdracht vanuit de politie is vaak beperkt. Concrete opdrachten worden weinig gegeven en terugkoppeling ontbreekt vaak. ${ }^{19}$

In Nederland worden ook private beveiligers ingezet als toezichthouders in private en semipublieke ruimten, zoals bedrijventerreinen, bij evenementen en grote winkelcentra. ${ }^{20}$ De taken van deze private beveiligers liggen vooral in toezicht, bewaking, en service. Daarnaast komt het in Nederland op beperkte schaal voor dat private beveiligers in opdracht van private partijen werkzaam zijn in de publieke ruimte. Afgezien van bedrijventerreinen en horecagebieden gaat het daarbij onder meer om residential patrol in opdracht van bewoners van dure woonwijken. ${ }^{21}$

16 KplusV - Organisatieadvies, Inzicht in toezicht en handhaving veiligheid en leefbaarheid in de openbare ruimte, Arnhem: KplusV 2010.

17 Terpstra 2012.

18 Ministerie van Veiligheid \& Justitie, Circulaire Buitengewoon Opsporingsambtenaar 2014.

19 R. van Steden en E. Bron, Gemeentelijke handhavers in Amsterdam, Den Haag: Boom-Lemma, 2012; Terpstra 2012; Eikenaar \& Van Stokkom 2014.

20 R. van Steden, Privatizing policing: Describing and explaining the growth of private security, Den Haag: Boom Juridische uitgevers 2007.

21 Terpstra, Van Stokkom \& Gunther Moor 2010. 
Concluderend: Nederland kent heden ten dage een gevarieerd en gefragmenteerd complex van publieke en particuliere toezichthouders en handhavers werkzaam in de openbare en semiopenbare ruimte. De relaties tussen hen en de (reguliere) politie zijn vaak tegenstrijdig. De coördinatie is daarbij gebrekkig.

\section{Pluralisering in vier landen}

Voor elk van de vier onderzochte landen wordt in het volgende een korte beschrijving gegeven van de huidige stand van zaken met betrekking tot plural policing. Daarbij wordt tevens ingegaan op de positie van publieke en private toezichthouders/handhavers, de relatie met de (reguliere) politie en de factoren die hebben bijgedragen aan de ontwikkeling naar een pluralistisch bestel. Deze elementen worden hier niet volgens een vast sjabloon gepresenteerd, zowel om redenen van leesbaarheid, als omdat dat niet zou passen bij de grote verschillen tussen de landen. De volgorde waarin de landen worden besproken, is van minste beïnvloeding door het neoliberaal gedachtegoed (Oostenrijk), naar de landen met een sterkere invloed van het neoliberaal denken (Canada).

\section{Oostenrijk}

Oostenrijk kent een relatief sterke legalistische cultuur. De thematiek van plural policing wordt hier (bijna) uitsluitend geïnterpreteerd in juridische termen. Het geloof in de staat en in hiërarchische verhoudingen is relatief sterk. Er is een politieke consensus dat alleen de staat verantwoordelijk is voor politiewerk en veiligheidszorg. Toch heeft ook Oostenrijk de afgelopen jaren een pluralisering doorgemaakt van toezicht en handhaving in de publieke ruimte, zij het op bescheiden schaal.

Oostenrijk heeft twee soorten politiekorpsen. Sinds 2005 is er de federale politie (Bundespolizei), waarbij de meeste politiemensen verdeeld zijn over meer dan negenhonderd politiezones. Daarnaast heeft een beperkt aantal (37) gemeenten (vooral in Tirol en Vorarlberg) een eigen (vaak klein) gemeentelijk politiekorps. Het aantal gemeentelijke politiekorpsen is sinds de Tweede Wereldoorlog teruggelopen. Een van de redenen is dat gemeenten een eigen korps volledig zelf moeten financieren. Grote steden als Wenen, Graz en Linz is het overigens wettelijk niet toegestaan een eigen politiekorps te hebben.

Sinds 2007 kent Oostenrijk op lokaal niveau een groei van twee soorten nietpolitieel politiewerk. Deze ontwikkelingen vertonen enige overeenkomsten met die in Nederland. Ten eerste hebben bijna twintig steden eigen organisaties met geüniformeerde medewerkers die verantwoordelijk zijn voor toezicht en (in mindere mate) handhaving in de openbare ruimte. Deze gemeentelijke organisaties hebben verschillende namen, zoals Ordnungsdienst en Stadtwache. De bevoegdheden van de gemeentelijke medewerkers zijn doorgaans minimaal en gaan niet verder dan het zogenoemde Jedermannsrecht. In enkele gevallen (als de stad Graz) hebben deze functionarissen enkele bevoegdheden, zoals het opleggen van een bestuurlijke boete bij overtreding van lokale regels. 
Verschillende factoren hebben bijgedragen aan de introductie van deze lokale ordediensten. Hoewel Oostenrijk een relatief laag niveau van criminaliteit heeft, werd in de jaren negentig veiligheid een belangrijke politieke kwestie. Lokale overheden waren van mening dat het zichtbaar toezicht op straat moest worden versterkt. Omdat de afgelopen tien jaar de afstand tussen (federale) politie en lokale gemeenschappen is vergroot (nationale prioriteiten werden voor de politie belangrijker, sinds 2005 werden meer dan 120 politiebureaus gesloten) ontstond lokaal een vacuüm in de veiligheidszorg. Mede vanwege het wettelijk verbod voor de grote steden een eigen politiekorps te hebben, besloten de grote steden hun eigen toezichtorganisaties op te richten.

Daarnaast hebben sinds ongeveer 2005 naar schatting veertig tot vijftig vooral middelgrote gemeenten particuliere beveiligers gecontracteerd die in de publieke ruimte worden ingezet. Deze gemeenten hebben geen gemeentelijke politie of gemeentelijke Ordnungsdienst. De redenen voor het inschakelen van beveiligingsbedrijven is vergelijkbaar met de overwegingen waarom grote steden Ordnungsdiensten hebben opgericht: de behoefte aan meer geüniformeerd toezicht op straat waaraan door de federale politie niet wordt voldaan. De bevoegdheden van door gemeenten gecontracteerde particuliere beveiligers is eveneens beperkt tot het Jedermannsrecht.

In de afgelopen tien tot vijftien jaar heeft de particuliere beveiliging in Oostenrijk een meer zichtbare rol verworven in de semipublieke en publieke ruimte. ${ }^{22}$ Oostenrijk heeft geen speciale wetgeving ter regulering van particuliere veiligheidszorg. Als gevolg hiervan is het mogelijk dat particuliere beveiligers op straat met vuurwapens rondlopen, bijvoorbeeld ter bewaking van een bank.

\section{België}

Ook in België zijn sinds de jaren negentig verschillende vormen van niet-politieel toezicht opgekomen. Deze ontwikkeling werd mede ingegeven door een toenemende onvrede onder burgers over kleine criminaliteit, overlast en sociale wanorde. Vanwege de opkomst van de extreem rechtse politieke partij Vlaams Blok voelden vooral de sociaaldemocratische lokale bestuurders zich verplicht hun slagvaardigheid in de aanpak van onveiligheid te tonen. Evenals in Nederland zijn werkgelegenheidsmaatregelen voor langdurig werklozen gebruikt om banen te creëren in het toezicht en de handhaving. Ook in België werd politie en vooral Openbaar Ministerie verweten de aanpak van overlast, wanorde en kleine criminaliteit te verwaarlozen. Om die reden werd in 1999 de GAS-wet (Wet Gemeentelijke Administratieve Sancties) ingevoerd om gemeenten meer armslag te geven de veiligheidszorg zelf te organiseren.

Pas sinds 2007 zijn de Belgische gemeenten in staat dit GAS-systeem effectief te benutten. Naast gemeenschapswachten konden toen gemeenschapswachtenvaststellers worden aangesteld. Terwijl de eerste groep alleen een preventieve rol heeft (het aanspreken van burgers en hen stimuleren de regels beter na te leven),

22 W. Fuchs, Private Sicherheitsdienste und öffentlicher Raum. Ein Überblick über die öffentlichenrechtlichen Rahmenbedingungen in Österreich mit rechtstatsächlichen und kriminologischen Anmerkungen (diss. Innsbruck), Innsbruck: Universität Innsbruck 2005. 
bestaat de laatste categorie uit handhavers die bevoegd zijn voor bepaalde overtredingen een rapport op te stellen. ${ }^{23}$ Dit verslag wordt naar een sanctionerend ambtenaar gestuurd die vervolgens een sanctie (boete) kan opleggen of bemiddeling kan voorstellen.

De uitvoering van dit stelsel varieert lokaal sterk. Zo zijn in Wallonië nauwelijks gemeenschapswachten-vaststellers actief, terwijl in Vlaanderen deze functionarissen op ruimte schaal worden ingezet. Hier bestaat ook de neiging deze vaststellers - zoals in Nederland met de boa's het geval is - meer bevoegdheden te geven. Het verschil tussen de twee delen van België hangt samen met uiteenlopende opvattingen over veiligheidszorg en de rol van de overheid daarbij. In Wallonië overheerst de traditionele opvatting dat toezicht en handhaving in de publieke ruimte alleen politietaken zijn. ${ }^{24}$ Overigens laten onze lokale casestudies zien dat ook binnen Vlaanderen de verschillen groot zijn. Zo ligt in Antwerpen de nadruk veel meer op handhaving, terwijl de Stad Gent preventie door de gemeenschapswachten veel meer centraal stelt. ${ }^{25}$

Politie en gemeenschapswachten(-vaststellers) zijn wettelijk verplicht samen te werken. Anders dan in Nederland heeft de politie niet de regie over deze groep gemeentelijke functionarissen, maar ligt deze bij de gemeente of de stad. In de praktijk kan de relatie tussen politie en gemeenschapswachten(-vaststellers) verschillen. In Luik bijvoorbeeld is de politie dominant, terwijl in Antwerpen het gemeentebestuur de leiding heeft.

Particuliere beveiliging speelt in België in de publieke ruimte een zeer beperkte rol. Binnen sommige grote winkelcentra (privaat gebied) houden particuliere beveiligers toezicht. Recent worden soms beveiligers ingezet bij evenementen. Er bestaat consensus dat toezicht en handhaving in de openbare ruimte alleen door de overheid mogen worden uitgevoerd. Een publiek debat over de inzet van particuliere beveiligers in de publieke ruimte is in dat land nooit van de grond gekomen. ${ }^{26}$ Daarmee neemt België internationaal bezien een vrij unieke positie in.

\section{Engeland en Wales}

Sinds de jaren negentig wordt ook in Engeland en Wales de politie gezien als slechts een van de vele instanties die als taak hebben de uitvoering van toezicht en handhaving in de publieke ruimte. Belangrijk voor het begrijpen van plural policing in Engeland en Wales is dat sinds 2002 de belangrijkste categorie van nieuwe toezichthouders onderdeel uitmaakt van de politieorganisatie. Het gaat hier om de Police Community Support Officers (PCSO's). De sturing op hun werk vindt ook vanuit de politie plaats. Ze hebben minder opleiding en minder bevoegdheden dan gewone politieagenten en zijn niet volledig beëdigd. Ze werken vooral op straat. Omdat zij een politie-uniform dragen (met op de rug het

23 E. Devroe, A swelling culture of control? De genese en toepassing van de wet op de gemeentelijke administratieve sancties in België (diss. Leuven), Antwerpen: Maklu 2012.

24 Devroe 2012.

25 Terpstra, Van Stokkom \& Spreeuwers 2013.

26 Devroe 2012. 
opschrift POLICE community support officer), vergroten zij de zichtbare aanwezigheid van de politie in de publieke ruimte en vervullen daarmee een 'reassurance'-functie: het geruststellen van burgers en het tegengaan van onveiligheidsgevoelens. In Engeland en Wales lijken de PCSO's inmiddels het dagelijks gezicht van de politie in belangrijke mate te bepalen. Het publiek heeft vooral contact met hen. Evaluatiestudies ${ }^{27}$ laten zien dat de PCSO's veel tijd besteden aan kleine criminaliteit, 'antisociaal gedrag' en aan alcohol gerelateerde problemen. Bewoners lijken meer bereid met hen contacten aan te knopen dan met reguliere politieagenten. Ze blijken vaak tevreden met de PCSO's, vooral wanneer ze persoonlijk bekend zijn.

In Engeland en Wales is er dus een 'politieoplossing' voor de behoefte aan meer toezicht en regulering op straat gekomen. Naast de PCSO's zijn er echter nog verschillende soorten wardens betrokken bij het toezicht binnen de lokale veiligheidszorg. Het gaat om surveillanten zonder extra bevoegdheden die meestal in dienst zijn van gemeenten, soms ook van woningcorporaties. Onderzoek laat positieve bevindingen zien over de inzet van de wardens. ${ }^{28}$ De afgelopen jaren is fors bezuinigd op de financiering van de nationale Warden Schemes. Gemeenten moeten nu in hun eigen financiering voorzien. Bovendien lijken veel gemeenten de voorkeur te geven aan functionarissen met handhavingsbevoegdheden.

In Engeland en Wales komt het op relatief grote schaal voor dat particuliere beveiligers werkzaam zijn in de semipublieke ruimte, zoals in grote winkelcentra of evenemententerreinen. ${ }^{29}$ Daarbij werken politie en particuliere beveiligers meestal nauw samen, onder meer door informatie-uitwisseling. ${ }^{30}$

Daarentegen komt het in Engeland en Wales weinig voor dat particuliere beveiligers toezicht houden in de publieke ruimte. ${ }^{31}$ Groei van dit verschijnsel wordt in het algemeen niet verwacht, ook niet in de Business Improvement Districts. ${ }^{32}$ De politie staat gereserveerd tegenover residential patrols, particuliere beveiligers die in opdracht van bewoners toezicht houden in woonwijken. ${ }^{33}$

Op grond van Community Safety Accreditation Schemes kunnen wardens en private beveiligers bescheiden politiële bevoegdheden krijgen (op grond waarvan zij voor kleine overtredingen een boete kunnen uitschrijven). ${ }^{34}$ Anders dan wardens komen particuliere beveiligers lang niet altijd in aanmerking voor deze regeling.

27 C. Cooper e.a., A national evaluation of Community Support Officers, Londen: Home Office 2006; C. Paskell, 'Plastic Police' Or 'Community Support'?: The Role of Police Community Support Officers Within Low-Income Neighbourhoods, European Urban and Regional Studies 2007, 14 (4), p. 349-361.

28 A. Crawford, 'Fixing Broken Promises?': Neighbourhood Wardens and Social Capital, Urban Studies 2006, 43 (5/6), p. 957-976.

29 T. Jones \& T. Newburn, The United Kingdom, in: T. Jones \& T. Newburn (red.), Plural policing: A comparative perspective, Londen: Routledge 2006, p. 34-44; Crawford e.a. 2005.

30 A. Wakefield, Selling Security: The Private Policing of Public Space, Cullompton: Willan 2003.

31 Wakefield 2005.

32 I. Cook, Policing, Partnerships, and Profits: The Operations of Business Improvement Districts and Town Centre Management Schemes in England, Urban Geography 2010, 31 (4), p. 453-478.

33 L. Noaks, Private cops on the block: A review of the role of private security in residential communities, Policing and Society 2000, 10 (2), p. 143-61.

Crawford e.a. 2005. 
Belangrijke reden is de weerstand binnen de politie tegen de inzet van particuliere beveiligers in de openbare ruimte.

\section{Canada-Ontario}

Kenmerkend voor Canada is dat op het terrein van (plural) policing het onderscheid tussen publiek en privaat in belangrijke mate aan duidelijkheid heeft verloren. De begrippen lijken soms fluïde en in elkaar over te gaan: publieke actoren (politiemensen) worden ingezet voor private doelen of gecontracteerd door private partijen, en private actoren lijken soms de rol van publieke toezichthouder op zich te nemen.

In Canada is naast de reguliere politie een groot aantal organisaties en beroepsgroepen verantwoordelijk voor toezicht in de openbare ruimte. Ten eerste zijn er publieke functionarissen, zoals special constables (ook wel 'parapolicing officers' genoemd) en by-law enforcement officers. Special constables werken bijvoorbeeld op universitaire campussen, maar ook in het openbaar vervoer. ${ }^{35}$ Het gaat om professionele, beëdigde peace officers die worden benoemd door de lokale police services boards maar in dienst zijn van hun eigen organisatie, zoals universiteit of ziekenhuis. De Police Services Act van Ontario maakt het mogelijk dat special constables voor hun werkgebied over politiebevoegdheden beschikken, zoals het zonder tussenkomst van de reguliere politie aanhouden en tijdelijk vastzetten van burgers voor minder ernstige delicten. ${ }^{36}$

By-law enforcement officers zijn bevoegd gemeentelijke regels met betrekking tot onder andere parkeren en geluidsoverlast te handhaven. Deze functionarissen worden beëdigd als provinciale offences officers, maar niet als special constables. De bevoegdheden van deze functionarissen, evenals hun uitrusting, variëren per gemeente.

De (reguliere) politie is in Ontario ook actief op de markt van veiligheid en orde. Beëdigde politiemensen worden in het kader van paid duty policing gecontracteerd door private opdrachtgevers om toezicht te houden bij evenementen en festiviteiten. Stadions als het Toronto SkyDome huren op deze basis politieagenten in. Soms wordt in gemeentelijke vergunningen vastgelegd dat een evenement slechts mag plaatsvinden onder voorwaarde dat paid duty police officers worden ingehuurd.

In Canada werken ongeveer tweemaal zoveel particuliere beveiligers als publieke politiemensen. ${ }^{37}$ De beveiligingsbranche biedt tal van diensten in de handhaving en misdaadbestrijding. Zo worden in Business Improvement Areas particuliere beveiligers gecontracteerd, vooral om antisociaal gedrag te bestrijden. ${ }^{38}$ Veel woningcorporaties huren beveiligers in om overlast door daklozen, hangjongeren en graffiti tegen te gaan. Illustratief is dat het beveiligingsbedrijf Intelligarde

35 E. Carroll, A Report on University Campus Policing and Security in Canada, Ottawa: Law Commission of Canada 2004 (Background paper prepared for the Law Commission of Canada); Rigakos \& Leung 2006.

36 Carroll 2004.

37 Law Commission of Canada, In Search of Security: The Future of Policing in Canada, Ottawa 2006, p. 25.

38 Law Commission 2006; Rigakos \& Leung 2006. 
International zich nadrukkelijk presenteert als 'The law enforcement company'. Het bedrijf houdt onder meer toezicht in commerciële centra. ${ }^{39}$

Het voorgaande laat zien dat in Canada de functies van politie en private beveiliging zich in belangrijke mate hebben vermengd. Zo fungeren beveiligers als politieagenten, hoewel ze geen bevoegdheden hebben. Ze ondervragen en verwijderen burgers, of leveren burgers die problematisch gedrag vertonen aan de politie over, ook in de publieke ruimte. Zij maken daarbij vaak op willekeurige wijze gebruik van het citizen's arrest. Overigens, ook in Canada zelf roept deze verregaande privatisering van toezicht en handhaving in de publieke ruimte veel vragen en discussie op, onder meer over de deskundigheid van privaat personeel en de democratische verantwoording. ${ }^{40}$

\section{Verschillen}

Evenals in Nederland heeft zich in alle vier hier beschreven landen de afgelopen twee decennia een duidelijk pluralisering van toezicht en handhaving in de publieke ruimte voorgedaan. De omstandigheden die daaraan hebben bijdragen, komen sterk overeen met die in Nederland. In al deze landen komt de politie onvoldoende tegemoet aan de verwachting dat ze zichtbaar aanwezig is in de publieke ruimte. Omdat dit probleem vooral op lokaal niveau wordt ervaren, wordt juist daar naar oplossingen gezocht. Om die reden is plural policing meestal een sterk lokaal gebonden verschijnsel. ${ }^{41}$ Daarnaast doen zich belangrijke verschillen voor in de wijze waarop het nieuwe toezicht in de publieke ruimte is georganiseerd en opereert. We bespreken de vier belangrijkste aspecten.

\section{Formele regulering}

Nederland kent verschillende juridische kaders ten behoeve van het niet-politieel toezicht en handhaving in de publieke ruimte. Terwijl de invulling van de taken van stadswachten wordt overgelaten aan de lokale overheden, zijn de taken en werkdomeinen van de boa's vastgelegd in een ministeriële circulaire. De handhavingsbevoegdheden van de boa's in de publieke ruimte berusten op de Wet bestuurlijke boete overlast in de openbare ruimte en vooral op de bestuurlijke strafbeschikking. De regulering van de private veiligheidszorg berust op de Wet particuliere beveiligingsorganisaties en recherchebureaus.

Zowel naar mate als wijze van regulering laten de vier andere landen een zeer divers beeld zien. België kent het duidelijkst een wettelijk raamwerk. De gemeenschapswachten werken in het kader van de Wet op de Gemeenschapswachten waarin ook hun organisatorische positie is vastgelegd. Vaststellingsbevoegdheid en het vervolgens opleggen van gemeentelijke administratieve sancties worden ontleend aan de GAS-wet. Daarmee is ook een wettelijk kader geboden voor de

39 Rigakos 2000, p. 154.

40 S. Burbidge, The Governance Deficit: Reflections on the Future of Public and Private Policing in Canada, Canadian Journal of Criminology and Criminal Justice 2005, 47 (1), p. 63-86; Law Commission 2006.

41 Terpstra, Van Stokkom \& Spreeuwers 2013, p. 136-141. 
relatie en taakverdeling tussen politie en gemeenschapswachten met vaststellingsbevoegdheid.

Zowel Oostenrijk als Canada heeft een aanzienlijk zwakker reguleringskader dan Nederland. Weliswaar berust in Oostenrijk de plicht tot handhaving van lokale verordeningen bij de gemeente, maar daaraan kunnen geen bijzondere bevoegdheden worden ontleend voor lokale toezichthouders. Met uitzondering van Stiermarken gaan hun bevoegdheden niet verder dan het Jedermannsrecht. De inrichting van de Ordnungsdienst wordt geheel aan de gemeente overgelaten. In Oostenrijk ontbreekt een specifiek wettelijk kader voor de private beveiligingssector. In Canada is een dergelijke wet sinds 2009 van kracht, maar de invloed ervan wordt in de regel als beperkt omschreven.

Engeland en Wales nemen met hun police community support officers in dit verband een bijzondere positie in. Omdat deze werkzaam zijn binnen de politieorganisatie, ontlenen zij daaraan het kader op basis waarvan zij hun werk doen. Sinds 2001 beschikken Engeland en Wales ook over een wet ter regulering van de private veiligheidszorg. ${ }^{42}$

Overigens, een wettelijk kader zegt vaak nog niet zo veel over de wijze waarop het niet-politieel toezicht/handhaving in de lokale praktijk plaatsvindt. Zo bestaan bijvoorbeeld in België grote verschillen tussen Vlaanderen en Wallonië in de wijze waarop de wetten op gemeentelijke administratieve sancties en gemeenschapswachten worden uitgevoerd.

\section{Scheiding of integratie}

In Nederland bestaat geen strikte scheiding tussen politie en boa's werkzaam in de publieke ruimte. De politie is ook bevoegd op te treden voor 'boa-waardige feiten'. In Nederland ligt bovendien de operationele regie over de boa's in het publiek domein bij de politie.

Op het punt van scheiding of integratie tussen reguliere politie en niet-politieel toezicht/handhaving laat elk van de landen een ander beeld zien, lopend van strikte scheiding tot verregaande integratie. Oostenrijk kent een strikte, deels wettelijk bepaalde scheiding tussen verantwoordelijkheden van de politie en die van de gemeente (waaronder de Ordnungsdienste, Stadtwache en gecontracteerde private toezichthouders vallen). In de praktijk opereren politie en gemeentelijke ordediensten of door gemeenten gecontracteerde private beveiligers vaak los van elkaar.

In België is sprake van een duidelijke taakverdeling tussen gemeenschapswachten-vaststellers en politie: op basis van uiteenlopende typen 'inbreuken' zijn er verschillende GAS-procedures voor politie en gemeente. Daarnaast zijn politie en gemeentelijke vaststellers wettelijk verplicht tot samenwerking. In de praktijk kan het lokaal sterk verschillen of en hoe dit gebeurt.

Een voorbeeld van een verregaande integratie bieden Engeland en Wales. Hier maken de nieuwe toezichthouders in de vorm van de police community support officers deel uit van de politieorganisatie. Bovendien zijn er op lokaal niveau ver-

42 A. White, The Politics of Private Security: Regulation, Reform and Re-legitimation, Basingstoke: Palgrave Macmillan 2010. 
plichte partnerships en neighbourhood teams waarbinnen politie en nieuwe toezichthouders/handhavers samenwerken.

De situatie in Canada is op dit punt hybride. Enerzijds is er een nauwe verwantschap tussen politiemensen, special constables en by-law officers, simpelweg omdat het in alle gevallen om peace officers gaat. Anderzijds bestaat er aanzienlijke afstand tussen deze groepen en de private beveiligers die een belangrijk deel van het toezicht- en handhavingswerk in de (semi)publieke ruimte op zich nemen.

\section{Privatisering}

In Nederland wordt het grootste deel van het nieuwe toezicht in de publieke ruimte uitgevoerd door publieke functionarissen als stadswachten en boa's. Op beperkte schaal is in Nederland daarnaast sprake van privatisering van het nietpolitiële toezicht/handhaving. Ongeveer een op de zeven gemeenten huurt private beveiligers in voor boa-werkzaamheden op straat. Op een beperkt aantal locaties in Nederland surveilleren beveiligers in het kader van privaat gefinancierde residential patrol in de openbare ruimte. In de semipublieke ruimte zijn grote aantallen private beveiligers werkzaam als toezichthouder.

De contrasten zijn het grootst met enerzijds België en anderzijds Canada. In België bestaat nauwelijks privaat toezicht in de publieke ruimte. De weerstand hiertegen lijkt nog altijd groot. De rol van private beveiligers beperkt zich hier tot private en semipublieke gebieden. In Canada gaat de privatisering van toezicht/ handhaving van alle onderzochte landen het verst. Met een omvangrijke private veiligheidssector in de (semi)publieke ruimte en privatisering van publiek politiewerk door uitbesteding heeft hier het traditionele onderscheid tussen publieke en private veiligheidszorg veel van zijn scherpte verloren.

De situatie in de twee andere landen (Oostenrijk en Engeland en Wales) vertoont op dit punt meer overeenkomsten met Nederland (hoewel er onderling belangrijke verschillen bestaan). Dat is opmerkelijk gelet op het feit dat de invloed van het neo-liberaal denken - inclusief steun aan privatisering - op deze twee Europese landen juist sterk verschilt.

\section{Bevoegdheden}

In Nederland bestaan er tussen de verschillende categorieën nieuwe toezichthouders in de publieke ruimte aanmerkelijke verschillen in bevoegdheden en dwangmiddelen. Deze variëteit treedt ook op in de andere onderzochte landen.

In Nederland beschikken stadswachten niet over bijzondere bevoegdheden. Dit komt overeen met de gemeenschapswachten in België en de wardens in Engeland en Wales. Met uitzondering van Stiermarken hebben in Oostenrijk medewerkers van de gemeentelijke Ordnungsdiensten evenmin bevoegdheden die verder gaan dan het Jedermannsrecht.

De sanctionerende mogelijkheden van de Nederlandse boa's werkzaam in de openbare ruimte zijn gebaseerd op de bevoegdheid van de gemeente een bestuurlijke boete of een bestuurlijke strafbeschikking op te leggen. Vergelijkbaar zijn de gemeenschapswachten-vaststellers in België, de PCSO's in Engeland en Wales en de special constables en by-law officers in Canada die eveneens sanctionerende middelen kunnen inzetten bij de handhaving. 
Private beveiligers werkzaam in semipublieke gebieden kunnen in de meeste onderzochte landen personen de toegang ontzeggen, soms ook personen verwijderen. Dit is ontleend aan bijvoorbeeld het Hausmannsrecht in Oostenrijk of trespassing laws in Canada. In het publieke domein beschikken zij in de regel niet over bijzondere bevoegdheden. Hierop zijn enkele uitzonderingen, zoals in Nederland de private beveiliger die als boa wordt ingehuurd door een gemeente. In Oostenrijk en België ontbreekt een dergelijk verschijnsel geheel. In Engeland en Wales kunnen private beveiligers de bevoegdheid krijgen een bekeuring uit te schrijven wanneer zij daartoe door de korpschef geaccrediteerd zijn. In Canada worden private beveiligers soms aangesteld als by-law enforcement officer.

In Nederland kunnen alleen de publieke boa's beschikken over dwangmiddelen: handboeien, pepperspray en wapenstok. In de andere bestudeerde landen (met uitzondering van (anada) is er doelbewust van afgezien de nieuwe toezichthouders dergelijke dwangmiddelen te geven. Men vreest dat anders het werk te veel op regulier politiewerk zou gaan lijken. Ook het verschijnsel dat in Nederland private beveiligers die als boa voor een gemeente werken over handboeien beschikken, lijkt in Europees verband een unicum. Daarentegen is het Oostenrijkse verschijnsel dat een private beveiliger met een geweer op straat loopt bij de bewaking van bijvoorbeeld een bankgebouw, in Nederland ondenkbaar.

Uit deze vergelijking blijkt opnieuw hoe groot de diversiteit is, ook binnen de afzonderlijke landen. Nederland neemt bij de hier onderscheiden dimensies vaak een middenpositie in. De verschillen tussen de landen hangen met vele factoren samen, waaronder de heersende opvattingen over de positie van de staat, de invloed van neoliberale opvattingen en van het New Public Management, en ontwikkelingen in de private veiligheidssector. Ook spelen hier een rol de verhoudingen tussen centrale en landelijke overheden, de aard van het politiebestel, het lokaal functioneren van de politie, de verhouding tussen lokaal bestuur en politie, specifieke juridische randvoorwaarden en regelingen, alsmede politieke verhoudingen en gevoeligheden. ${ }^{43}$

\section{Discussie: de toekomst van plural policing in Nederland}

De hier geschetste ontwikkelingen roepen veel vragen op. Het proces van pluralisering is niet zozeer het resultaat van een gericht beleid door de overheid, maar eerder uitvloeisel van incrementele en blinde processen met een grote diversiteit en lokale variatie waarbij tal van instanties betrokken zijn. Het verloop van deze complexe, zich min of meer autonoom voltrekkende ontwikkelingen is moeilijk te voorspellen.

Tegen die achtergrond bezien is het van belang beter zicht te krijgen op mogelijke ontwikkelingen die zich in de toekomst in Nederland kunnen voordoen. In deze paragraaf worden daarom twee beleidsperspectieven geschetst. Daarbij wordt 
voortgebouwd op de in het voorgaande beschreven patronen en ontwikkelingen met betrekking tot toezicht en handhaving in de onderzochte landen.

Vooraleer op deze twee perspectieven in te gaan, geven we eerst aan welke kernproblemen het onoverzichtelijke bestel van plural policing met zich meebrengt. Ten eerste, zoals opgemerkt, is lang niet altijd duidelijk welke instantie de regie en coördinatie op zich zou moeten nemen. Ten gevolge van de aanzienlijke fragmentatie die in het toezicht en de handhaving is ontstaan, worden echter juist hoge eisen gesteld aan die coördinatie. Ten tweede bestaat het risico dat de veiligheidszorg onvoldoende voldoet aan de eisen die aan een publiek goed gesteld mogen worden, zoals het afleggen van verantwoording aan democratische lichamen.

Dat laatste heeft vooral betrekking op de 'sluipende' groei van de private beveiligingsbranche. Met een verdergaande vermarkting zou een three tier system of policing kunnen ontstaan: naast het publieke 'aanbod' van toezicht en handhaving door politie en gemeenten, ook nog privaat toezicht en handhaving, deels voor ondernemers en burgers die dat kunnen betalen, deels als ingehuurde boa's die als 'wegwerptoezichthouders' moeten voldoen aan de gemeentelijke behoefte tot een flexibele organisatie. ${ }^{44}$ Dit proces heeft zich in Canada grotendeels voltrokken. Er lijkt weinig bij te winnen als Nederland ook die weg zou opgaan. De overheveling van taken en verantwoordelijkheden naar de markt levert mogelijk besparingen op, maar dat weegt - afgaande op Canadese ontwikkelingen - niet op tegen de onvrede van de bevolking over de gebrekkige kwaliteit van het publieke optreden van beveiligers (zoals escalerende situaties op straat en te snel toepassen van het citizen's arrest). Bovendien leert Canada dat een eenmaal ingeslagen weg van privatisering nauwelijks meer is terug te draaien.

De prijs voor verdere privatisering kon wel eens hoog zijn, niet alleen voor het karakter van de veiligheidszorg, maar ook voor het aanzien en gezag van overheid en politie en het vertrouwen dat burgers daarin hebben. Overheid en politie kunnen niet ongestraft een kernopdracht als toezicht en handhaving verwaarlozen in de hoop dat een ondoorzichtig geheel van marktpartijen het zo ontstane gat zal vullen.

In de Nederlandse publieke ruimte bestaat vooralsnog een two-tier system of policing, namelijk een reguliere landelijke politie voor het 'echte en harde' politiewerk en een nieuwe 'gemeentepolitie' met weinig bevoegdheden, die er is voor het dagelijks toezicht, de zichtbaarheid en het contact op straat met burgers. Wat zijn op basis van dat systeem - en geplaatst tegen de achtergrond van voorgaande analyse - mogelijke opties voor toekomstig beleid rond toezicht en handhaving in het publiek domein in Nederland? De twee hieronder geschetste perspectieven verschillen vooral in het antwoord op de vraag wie de operationele regie en coördinatie van toezicht en handhaving in de openbare ruimte zou moeten vervullen.

\section{Perspectief 1: politie als regisseur}

De situatie in Engeland is kenmerkend voor dit perspectief: in dat land heeft de politie de coördinatie over toezicht en handhaving in de publieke ruimte. In 2003 
is ervoor gekozen om surveillancefunctionarissen met sanctiemiddelen - de psco's - bij de politie onder te brengen. Dat heeft evidente voordelen: de pcso's worden opgeleid en getraind binnen de politieorganisatie; ze werken in dezelfde teams samen met gewone agenten (constables). De politie beschikt over de voor dit terrein relevante deskundigheid en ervaring. Op die manier kunnen democratische controle en 'gezagvolle sturing' beter worden gerealiseerd. Binnen dit integratiemodel hoeft geen einde te komen aan de spreiding van toezichttaken over verschillende partijen en instellingen (private beveiligers; straatcoaches; buurtwachten; huismeesters; enzovoort), maar blijven de handhavende bevoegdheden bij de politie. Daardoor ontstaan minder coördinatie- en afstemmingsproblemen.

Ook in Nederland kent deze opvatting aanhangers, zij het dat deze visie in het huidige politieke debat zich niet sterk manifesteert. Eerder lijkt de neiging te bestaan de pluralisering van de politiefunctie te beschouwen als onvermijdelijk proces. Het is echter minstens ook uitkomst van politieke (deel)beslissingen in het verleden. Los daarvan blijft de vraag in hoeverre zich deze pluralisering nog laat terugdraaien.

Is het onderbrengen van alle handhaving op straat bij de politie nog realiseerbaar, of is inmiddels daarvoor de geest te ver uit de fles? Het mislukte 'avontuur' met de politiesurveillanten is daarvoor illustratief. Bovendien, heeft de politie in Nederland met haar terugtrekkende beweging, haar nadruk op kerntaken, haar verwaarlozing van het eenvoudige toezicht- en handhavingswerk, en de vaak geringschattende bejegening van gemeentelijke stadswachten en boa's ${ }^{45}$ niet haar beurt verspeeld?

De ervaringen met de zogenoemde operationele regie door de politie over de gemeentelijke boa's in het publiek domein ${ }^{46}$ geven evenmin veel reden van dit perspectief hoge verwachtingen te hebben. ${ }^{47}$

Veel leidinggevenden binnen de politie zijn van mening dat het een goede zaak is dat de politie niet langer wordt belast met alledaags toezicht en handhaving zodat ze zich kan bezighouden met urgentere zaken. De vraag is echter of de politie het zich überhaupt wel kan veroorloven om niet zichtbaar aanwezig te zijn op straat. Haar informatiepositie wordt er niet sterker op en mogelijk verliest zij aan gezag bij het publiek. Ondanks deze kanttekeningen is het voorstelbaar dat politiesurveillanten - opnieuw - toezicht en handhaving op straat voor hun rekening gaan nemen. Gemeentelijke handhavers die in de openbare ruimte werkzaam zijn, kunnen doorstromen naar de politieorganisatie (zoals in België mogelijk is).

Kortom, binnen dit perspectief wordt de centrale positie in het pluriforme veld van toezichthouders ingenomen door de politie. Nieuwe (publieke en private) toezichthouders in de publieke ruimte vormen geen probleem, zolang zij geen handhavende bevoegdheden hebben.

47 Na de brief van 1 april 2014 van minister Opstelten aan de Tweede Kamer is voortaan sprake van operationele regie door de politie betreffende 'de regie op samenwerking bij de dagelijkse uitvoering van handhavingsactiviteiten'. 


\section{Perspectief 2: gemeente als centrale partij}

In het tweede perspectief is de lokale overheid (gemeente) de centrale partij. De pluralisering van handhavende functies in de openbare ruimte wordt binnen dit perspectief als feit aanvaard (en niet bij voorbaat als negatieve ontwikkeling beschouwd). Dat betekent dat de betrokken partijen op samenwerking zijn aangewezen. Twee overwegingen spelen daarbij een rol. Ten eerste, de politie heeft haar krediet voor een belangrijk deel verspeeld door zich terug te trekken van het 'eenvoudige' lokaal toezicht- en handhavingswerk in de publieke ruimte. Ten tweede wordt ervan uitgegaan dat toezicht en handhaving bij de gemeente horen omdat zo afstemming met de rest van het lokale integrale veiligheidsbeleid mogelijk wordt.

De gemeente krijgt daardoor de kans 'haar tanden' te laten zien en vrijblijvendheid in het lokaal veiligheidsbeleid te vermijden. Met de positionering van het toezicht en de handhaving bij de gemeente wordt bovendien een directe link gelegd met het lokaal bestuur en is er meer ruimte voor democratische controle. In Nederland, maar ook in België en Oostenrijk zijn gemeenten steeds meer centrale instantie en coördinator van een geïntegreerd lokaal veiligheidsbeleid. In alle drie de landen zijn niet-politiële toezichthouders en handhavers daar grotendeels ondergebracht. In de Nederlandse verhoudingen lijkt dat in veel opzichten de meest voor de hand liggende optie. Het sluit aan bij de sinds begin jaren negentig gegroeide centrale positie van de gemeenten in het lokaal integraal veiligheidsbeleid.

Ook dit perspectief roept echter vragen op. In hoeverre beschikken de gemeenten over de deskundigheid en middelen om deze taak op zich te nemen? Is adequate coördinatie wel mogelijk als de van oorsprong belangrijkste toezichthoudende partij in het publiek domein, namelijk de politie, in belangrijke mate haar eigen weg gaat? Hoe zal zich dit verder ontwikkelen onder het gesternte van de Nationale Politie in Nederland? Ook het toebedelen van de beleidsregie over toezicht en handhaving aan de gemeente (of zo men wil: de driehoek) en de operationele regie aan de politie roept vragen op. De meeste betrokkenen zijn geen voorstander van 'operationele regie'. ${ }^{48}$ De veronderstelde samenwerking tussen politie en gemeentelijke toezichthouders komt dan ook moeizaam van de grond. Mogelijk kan hier iets geleerd worden van de wijze waarop in België verantwoordelijkheden zijn verdeeld tussen politie en gemeenschapswachten (inclusief gescheiden werkdomeinen) en van de (verplichte) samenwerking tussen hen op voet van gelijkheid.

\section{Slot}

In deze bijdrage zijn de Nederlandse ontwikkelingen rond toezicht en handhaving in de openbare ruimte vergeleken met die in vier andere landen: Oostenrijk, België, Engeland en Wales, en Canada (Ontario). Er zijn grote verschillen tussen de onderzochte landen. Bovendien zijn de verschillen binnen de afzonderlijke lan- 
den groot. Plural policing manifesteert zich in alle hier bestudeerde landen vooral op lokaal niveau, in antwoord op plaatselijke behoeften aan toezicht en aan het terugdringen van onveiligheid. Hoewel ook Oostenrijk en Wallonië hun eigen vormen van plural policing hebben, bestaat daar veel weerstand tegen de inzet van stadswachten (of gemeenschapswachten) en particuliere beveiligers op straat. De bevolking hecht daar nog altijd veel waarde aan het monopolie van de politie op handhaving. Canada daarentegen heeft een complex systeem van contract policing: zowel publieke als private partijen bieden hun diensten aan op de markt van toezicht en handhaving. Anders dan peace officers kunnen particuliere beveiligers echter nauwelijks verantwoordelijk worden gehouden voor hun publieke optreden. Engeland en Wales hebben hun eigen oplossing gevonden voor de versplintering van toezicht en handhaving: de introductie van de community support officers die onderdeel zijn van de reguliere politieorganisatie.

Ondanks deze verschillen zijn er tussen deze landen ook overeenkomsten: in geen van de besproken landen wordt policing voorgesteld of geclaimd als exclusieve taak van de politie. Naast de politie vervullen andere partijen een belangrijke rol in de veiligheidszorg. Met uitzondering van België worden private beveiligers regelmatig betrokken bij publiek toezicht. Deze ontwikkelingen hebben een complex en gevarieerd, maar ook onoverzichtelijk bestel van plural policing voortgebracht. Overal spelen daarbij problemen als fragmentatie, onvoorspelbaarheid en gebrek aan coördinatie en democratische verantwoording.

In het voorgaande zijn twee beleidsperspectieven voor Nederland geschetst. Aan de hand daarvan kan verdere gedachtevorming plaatsvinden over de toekomstige invulling van het toezicht en de handhaving in de publieke ruimte. De opgeworpen vragen kunnen aanleiding zijn het noodzakelijk debat hierover op gang te brengen. Te lang is de pluralisering van toezicht en policing als een blind en onvermijdelijk proces behandeld. Het wordt daarom tijd de gedachtevorming en het debat hierover op gang te brengen en na te gaan op welke wijze dit toezicht en deze handhaving het beste vorm kunnen krijgen.

Het is van groot belang dat duidelijke keuzes worden gemaakt vanuit een heldere en coherente visie op toezicht en handhaving in het publiek domein. Ook met de maatregelen die de minister de laatste jaren heeft genomen in het kader van het boa-bestel blijft het in belangrijke mate sleutelen in de marge. Op die wijze dreigt nog altijd een verdere fragmentatie van het toezicht en de handhaving in de publieke ruimte. 